\title{
Age-standardized cancer-incidence trends in Canada, 1971-2015
}

\author{
Darren R. Brenner PhD, Yibing Ruan PhD, Eileen Shaw MSc, Dylan O’Sullivan MSc, Abbey E. Poirier MSc, \\ Emily Heer MSc, Paul J. Villeneuve PhD, Stephen D. Walter PhD, Christine M. Friedenreich PhD, \\ Leah Smith PhD, Prithwish De PhD
}

Cite as: CMAJ 2019 November 18;191:E1262-73. doi: 10.1503/cmaj.190355

CMAJ Podcasts: author interview at https://soundcloud.com/cmajpodcasts/190355-res

\begin{abstract}
BACKGROUND: Although cancer incidence over time is well documented in Canada, trends by birth cohort and age group are less well known. We analyzed age- and sex-standardized incidence trends in Canada for 16 major cancer sites and all cancers combined.
\end{abstract}

METHODS: We obtained nationally representative population-based cancer incidence data in Canada between 1971 and 2015 from the National Cancer Incidence Reporting System (1969-1992) and the Canadian Cancer Registry (19922015). We analyzed cancer-incidence trends, reported as annual percent change (APC) for each 10-year group from age 20 to 89 years. We also esti- mated age-adjusted incidence rate ratios from fitted birth cohort models.

RESULTS: Across most age categories, the most recent trends show significant decreases in the incidence of cervical (APC $-8.8 \%$ to $-0.33 \%$ ), lung (men: $-7.42 \%$ to $-0.36 \%$; women: $-6.27 \%$ to $1.07 \%$ ), bladder (women: $-4.12 \%$ to $-0.07 \%$; men: $-5.13 \%$ to $-0.38 \%$ ) and prostate cancer $(-11.11 \%$ to $-1.11 \%)$. Significant increasing trends were observed for kidney, thyroid and uterine cancers. Overall incidence has increased among both sexes younger than 50 years of age, with recent increases in pancreatic cancer among men, breast cancer among women and colorectal cancer among both sexes. From the birth cohort analysis, we observed increasing trends in colorectal, liver and prostate cancers among men; kidney cancer and melanoma among women; and thyroid cancer among both sexes. We observed decreasing trends in cervical and ovarian cancers, and in bladder and lung cancers among men.

INTERPRETATION: Cancer incidence is decreasing at many sites targeted by primary-prevention efforts, such as smoking cessation and screening programs. Substantial increases in incidence among younger populations are driven by cancers possibly associated with obesity.
E xamination of historical data in Canada suggests that overall age-standardized incidence rates of cancer have decreased in males, but have increased in females. ${ }^{1}$ Among both males and females between 1992 and 2013, the annual percent change (APC) in age-standardized incidence rates varied considerably among cancer sites, with the largest proportional increases seen in thyroid and liver cancers, and the largest decreases seen in stomach and laryngeal cancers. ${ }^{1}$ However, analysis of age-standardized overall cancer rates may mask important epidemiologic trends for a given cancer site. For example, while overall rates of colorectal cancer are decreasing in Canada, we have previously shown that incidence is increasing substantially among adults younger than 50 years of age. ${ }^{2}$ This discrepancy highlights the importance of examining the long-term trends in age-standardized incidence by individual cancer sites, which may be missed in overall trends.
Age-standardized trends may provide insights that are of clinical or epidemiologic value, such as how previous primaryand secondary-prevention interventions affected the health of a population. Analysis by birth cohort can also help to inform hypotheses about potential early-life risk factors that have changed over generations. Finally, understanding cancerincidence trends specific to age and birth cohort can help guide future health-resource planning, as they may suggest health care needs of subpopulations. Although trends in cancer incidence have been well characterized in Canada for all ages combined, age- and birth cohort-specific trends have not been investigated for most cancer sites. In this study, we examined age- and birth cohort-specific incidence trends in Canada between 1971 and 2015 for 16 major cancer sites and all cancers combined. 


\section{Methods}

We obtained population-based cancer incidence data in Canada from 2 nationally representative registries: the National Cancer Incidence Reporting System (NCIRS) (1969-1992) ${ }^{3}$ and the Canadian Cancer Registry (CCR) (1992-2015). ${ }^{4}$ The CCR evolved out of the NCIRS and is a longitudinal database of individuals in whom cancer was diagnosed, in contrast to the earlier eventoriented NCIRS, which recorded events of tumour diagnosis in Canada. ${ }^{5}$ Based on the Union for International Cancer Control global status of cancer registration, the CCR is one of the highestquality national population-based cancer registries in the world. ${ }^{6}$

Complete cancer-incidence data were available in these databases for all provinces except Quebec, for which the most recent year of reported incidence data was 2010. Incidence data from 2011 to 2015 for Quebec were imputed for each sex-cancer site combination using the imputation method with the best overall performance (Appendix 1, available at www.cmaj.ca/lookup/ suppl/doi:10.1503/cmaj.190355/-/DC1).

The starting year for analysis was 1971 because of the quality and availability of data from some provinces. We examined trends in age-adjusted (to the 2011 Canadian census population) population cancer incidence in 10-year age groups. For cancer sites and age groups with low average incidence (< 1 per 100000 personyears), we used broader age categories. There was a change in reporting practices of bladder cancer in Ontario after 2012, at which point in situ cases were included. We used the jump model of the Joinpoint Regression Program, which was designed for the specific purpose of such changes. ${ }^{7}$ For the incidence of all cancers in Canada, we excluded nonmelanoma skin cancers, because most cancer registries do not collect incidence data on cases of nonmelanoma skin cancers. Discrepancies between the data sets from changes in cancer definitions over time were accounted for using methods that have been described previously. ${ }^{1}$ Briefly, from 1992 onward, cancer diagnoses were classified according to the International Classification of Diseases for Oncology, 3rd Edition. Before 1992, cancer diagnoses in the NCIRS were classified according to the equivalent codes from the International Statistical Classification of Diseases and Related Health Problems, Ninth Revision. The NCIRS data were edited, reformatted and recoded to generate a standardized record file. ${ }^{8}$ Any changes in cancer definitions over time were reviewed and accounted for by the Health Sciences Division at Statistics Canada. ${ }^{9}$

\section{Statistical analysis}

We used the Joinpoint Regression Program (version 4.5.0.1, Surveillance Research Program, National Cancer Institute) to fit joined lines on a logarithmic scale to observed rates, and to estimate the APCs in incidence. We analyzed log-transformed incidence rates with permutation analysis to fit a series of joined straight lines, with a minimum of 0 and a maximum of 4 joinpoints. The best-fit model was selected by the Joinpoint Regression Program by performing a series of comparisons among the fitted models, including significance testing for identifying changes in trends. Detailed information is available on the program's web page. ${ }^{10}$
We fit birth cohort models using the National Cancer Institute's web tool. ${ }^{11}$ Input data were aggregated cases and population for 14 five-year age groups (20-24 yr to 85-89 yr) and 9 fiveyear periods (i.e., 1971-1975 through 2011-2015). Cohort effects by sex are presented as incidence rate ratios (IRRs), adjusted for age, with the 1941 birth cohort as the reference.

\section{Sensitivity analysis}

We conducted a sensitivity analysis excluding Quebec to determine robustness of our results.

\section{Ethics approval}

Ethics approval for this research was granted by the Health Research Ethics Board of Alberta (HREBA.CC-14-0220).

\section{Results}

For these analyses, 5198560 total incident cancer cases diagnosed between 1971 and 2015 were included (Table 1). Slightly more men $(51.9 \%)$ than women $(48.1 \%)$ were diagnosed at included cancer sites. Cancer incidence rose with each 5-year period from 277540 cases in 1971-1975 to 880385 cases in 20112015. More than half of all incident cancers were diagnosed in people aged 60-79 years. Cancer incidence by age, sex and cancer site are presented in Appendix 2 (available at www.cmaj.ca/ lookup/suppl/doi:10.1503/cmaj.190355/-/DC1).

Overall, incidence of cancer among men is decreasing, which can be attributed to declines since 2007 among men older than 50 years (age 50-59 yr: APC -1.92, 95\% confidence interval $[\mathrm{Cl}]$ -2.36 to -1.47 ; age $60-69 \mathrm{yr}$ : APC $-2.30,95 \% \mathrm{Cl}-2.86$ to -1.75 ; age 70-79 yr: APC $-1.11,95 \% \mathrm{Cl}-1.32$ to -0.89 ; age $80-89$ yr: APC $-4.54,95 \% \mathrm{Cl}-5.35$ to -3.73$)$. Incidence has slightly increased among men in the younger age categories (age 20-29 yr: APC $0.86,95 \% \mathrm{Cl} 0.75$ to 0.97 ; age $30-39 \mathrm{yr}$ : APC $1.48,95 \% \mathrm{Cl} 1.08$ to 1.87; age $40-49$ yr: APC $0.24,95 \% \mathrm{Cl} 0.11$ to 0.38 (Figure 1 ).

Among women, incidence is increasing for most age groups, with the highest rate of increase in women aged 30-39 years (APC 1.39, 95\% Cl 1.19 to 1.59). Cancer incidence has decreased among women aged $80-89$ years, with an APC of $-6.76(95 \% \mathrm{Cl}$ -7.62 to -5.90 ) since 2009 (Figure 2). Trends for all selected cancer sites are summarized in Table 2.

\section{Recent trends}

We observed a decline in cervical cancer incidence, with significant trends observed in all age groups, except for the group aged 30-39 years, in which the recent change is not significant (APC -0.33 , $95 \% \mathrm{Cl}-1.16$ to 0.50$)$. The declining trend starts after 1981 for the group aged 20-29 years (APC $1.22,95 \% \mathrm{Cl}-0.98$ to 3.47, before 1981 ), and after 1979 for women aged $80-89$ years (APC $2.31,95 \% \mathrm{Cl}-1.01$ to 5.75, before 1979). For all other age groups, incidence was decreasing as of the start of incidence data in 1971 (Appendix 3, available at www.cmaj.ca/lookup/suppl/doi:10.1503/cmaj.190355/-/DC1).

Ovarian cancer has been decreasing among most age groups, with the exception of the group aged 20-29 years, in which a significant increase has been observed (APC $2.31,95 \% \mathrm{Cl} 0.54$ to 4.11 ), and in the group aged $40-49$ years, in which rates have been stable 
Table 1: Characteristics of included incident cancer cases ( $n=5198$ 560) in Canada from 1971 to 2015

\section{Characteristic}

No. $(\%)$ of cases

Patient sex

Female

Male

2501130 (48.1)

Patient age, yr

$\begin{array}{cc}20-29 & 76890(1.5) \\ 30-39 & 179760(3.5) \\ 40-49 & 430600(8.3) \\ 50-59 & 899170(17.3) \\ 60-69 & 1398270(26.9) \\ 70-79 & 1389585(26.7) \\ 80-89 & 824285(15.9)\end{array}$

Period

1971-1975

1976-1980

1981-1985

1986-1990

1991-1995

1996-2000

2001-2005

2006-2010

2011-2015

Cancer site or type

Acute myeloid leukemia

Anus

Bladder

Breast

Cervix

Chronic myeloid leukemia

Colon and rectum

Esophagus

Gallbladder

Kidney and renal pelvis

Larynx

Liver

Lung and bronchus

Multiple myeloma

Non-Hodgkin lymphoma

Oral

Ovary

Pancreas

Prostate

277540 (5.3)

347000 (6.7)

427145 (8.2)

490550 (9.4)

$581280(11.2)$

641025 (12.3)

$728920(14.0)$

824715 (15.9)

880385 (16.9)

$33230(0.6)$

$15750(0.3)$

236845 (4.6)

$699430(13.5)$

$65015(1.3)$

$17625(0.3)$

688305 (13.2)

$51470(1.0)$

$17945(0.3)$

$133210(2.6)$

$48995(0.9)$

$41900(0.8)$

759050 (14.6)

64585 (1.2)

195690 (3.8)

138665 (2.7)

$89070(1.7)$

131885 (2.5)

$611140(11.8)$

140060 (2.7)

132075 (2.5)

97935 (1.9)

$27575(0.5)$

153820 (3.0)

Uterus

All cancers recently (APC $0.70,95 \% \mathrm{Cl}-0.06$ to 1.46 ) (Appendix 3). Nevertheless, the incidence rates of these 2 age groups in 2015 were still similar to the rates in 1971 (age 20-29 yr: 2.26 per 100000 in 1971 and 2.47 per 100000 in 2015; 40-49 yr: 16.52 per 100000 in 1971 and 13.33 per 100000 in 2015).

Significant decreasing trends were observed for bladder cancer among all age groups in the most recent trend, with the exception of women age 70-79 years, in whom the trend was not significant.

We also observed significant increases in kidney cancer incidence across all age groups, except for groups aged $80-89$ years, in which there has been a significant decrease for both sexes (men: APC $-6.77,95 \% \mathrm{Cl}-9.23$ to -4.25 ; women: APC $-7.43,95 \%$ $\mathrm{Cl}-10.96$ to -3.76 ) (Appendix 3).

Uterine cancer incidence, according to the most recent trend, has been increasing significantly among women in all age groups, except for those aged 20-29 years, in whom incidence has been stable (APC $1.06,95 \% \mathrm{Cl}-0.81$ to 2.97 ), and in those aged 80-89 years, in whom incidence has been decreasing significantly (APC $-2.26,95 \% \mathrm{Cl}-2.82$ to -1.70 ) (Appendix 3).

The incidence of liver cancer has been increasing among women older than 60 years, with sharp increases observed in more recent years in the group aged 60-69 years (APC 6.73, 95\% $\mathrm{Cl} 3.03$ to 10.56). A steady increase in liver cancer incidence since 1971 was observed for most age groups among men, with APCs ranging from $0.95(95 \% \mathrm{Cl} 0.14$ to 1.77$)$ in the group aged $20-39$ years to $6.73(95 \% \mathrm{Cl} 3.03$ to 10.56$)$ in the group aged 60-69 years. The exception was the group aged 40-59 years, in which a recent slight but nonsignificant decline has been observed (40-49 yr: APC $-1.34,95 \% \mathrm{Cl}-3.36$ to 0.72 ; $50-59 \mathrm{yr}$ : APC $-1.62,95 \% \mathrm{Cl}-3.68$ to 0.49 ).

Melanoma incidence has also increased in all age groups, except in men aged $20-49$ years (APC $0.05,95 \% \mathrm{Cl}-0.16$ to 0.26 ) and women aged $20-39$ years (APC $0.21,95 \% \mathrm{Cl}-0.02$ to 0.44 ). In these groups, incidence rates have plateaued, and there has been a significant decline among men aged 20-29 years (APC $-2.59,95 \% \mathrm{Cl}-4.34$ to -0.80 ) (Appendix 3).

There have been large increases in rates of thyroid cancer across all age groups, with more substantial increases observed since the 1990s (Appendix 3).

Top cancer sites among men: prostate, colorectal and lung We observed a gradual increase in prostate cancer incidence rates among men aged 50-79 years between 1971 and the late 1980s (age 50-59 yr: APC 3.30, 95\% Cl 2.13 to 4.49; age 60-69 yr: APC 3.56, $95 \% \mathrm{Cl} 2.83$ to 4.29 ; age $70-79$ yr: APC $2.94,95 \% \mathrm{Cl} 2.45$ to 3.42), followed by a sharp increase between 1989 and 1993. In the age groups of 50-59 years and 60-69 years, the incidence rate kept rising until 2007 (age 50-59 yr: APC 5.18, 95\% Cl 4.31 to 6.06; 60-69 yr: APC $2.49,95 \% \mathrm{Cl} 1.62$ to 3.37 ), followed by a sharp decline afterward $(50-59 \mathrm{yr}$ : APC $-6.32,95 \% \mathrm{Cl}-7.61$ to -5.01 ; 60-69 yr: APC $-6.41,95 \% \mathrm{Cl}-7.42$ to -5.38$)$. In the age group of 70-79 years, the incidence rate quickly dropped to the level before the sharp rise in 1996, remained steady between 1996 and 2007 (APC $-0.68,95 \% \mathrm{Cl}-1.38$ to 0.02 ) and declined at an APC of $-5.35(95 \% \mathrm{Cl}-6.32$ to -4.37$)$ after 2007. In the age group of 80-89 years, the incidence rate gradually increased between 
1971 and 1993 (APC 2.06, 95\% Cl 1.75 to 2.37). After 1993, the incidence rate decreased from 1423 per 100000 in 1993 to 438 per 100000 in 2015 (Appendix 3).

Incidence of colorectal cancer has increased in men younger than 50 years and decreased in men older than 50 years (Figure 3). The most recent trend (up to 2015) shows increasing rates for men aged $20-29$ years (APC $6.36,95 \% \mathrm{Cl} 4.71$ to 8.05 ), 30-39 years (APC $5.29,95 \% \mathrm{Cl} 4.27$ to 6.31 ) and $40-49$ years (APC $1.94,95 \% \mathrm{Cl} 1.30$ to 2.57 ), and decreasing rates for men aged 50-59 years (APC $-1.03,95 \% \mathrm{Cl}-1.67$ to -0.38 ), 60-69 years (APC $-2.54,95 \% \mathrm{Cl}-3.17$ to -1.91 ]), $70-79$ years (APC $-1.92,95 \% \mathrm{Cl}-2.49$ to -1.34 ) and $80-89$ years (APC -5.29 ,
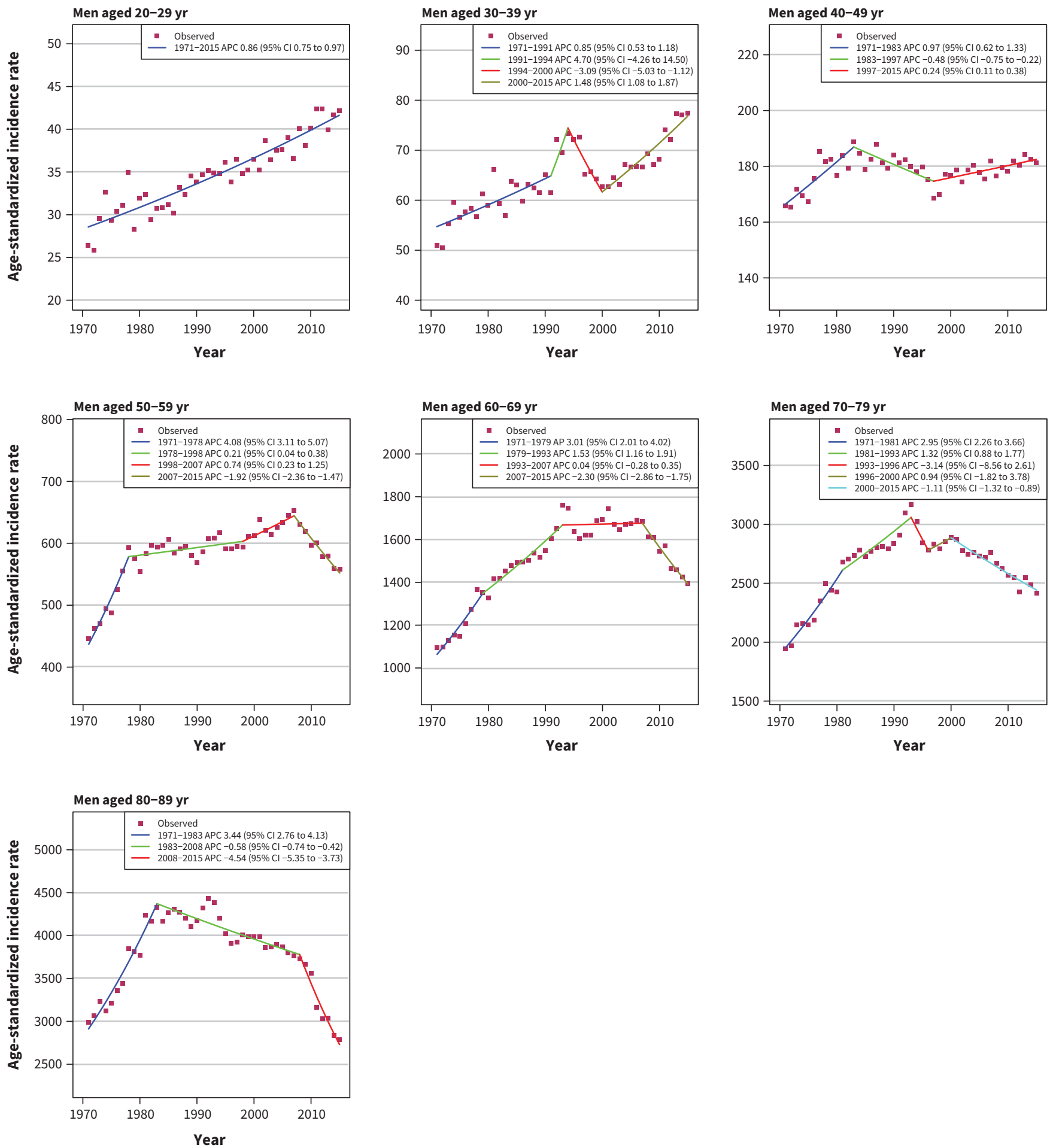

Figure 1: Age-standardized incidence rates of all cancers in men in Canada (1971-2015). Note: APC = annual percent change, $\mathrm{Cl}=$ confidence interval. 
$95 \% \mathrm{Cl}-6.32$ to -4.24$)$. Lung cancer incidence among men is decreasing in all age groups, with the largest decreases in the group aged $40-49$ years (APC $-7.42,95 \% \mathrm{Cl}-9.02$ to -5.79 ). No distinct trend could be discerned in the group aged 20-29 years, as incidence rate is very low, ranging from 0 to 0.7 per 100000 (Appendix 3).
Top cancer sites among women: breast, lung and colorectal Substantial increases in breast cancer incidence were observed in the 1980s and 1990s for all groups aged 50 years and older, with APC ranging from 1.33 (95\% $\mathrm{Cl} 1.13$ to 1.52 ) in those aged $60-69$ years to 2.38 (95\% $\mathrm{Cl} 1.86$ to 2.90 ) in those aged $50-59$ years (Figure 4). From late 1990 s to 2015 , rates have been stable in the group aged
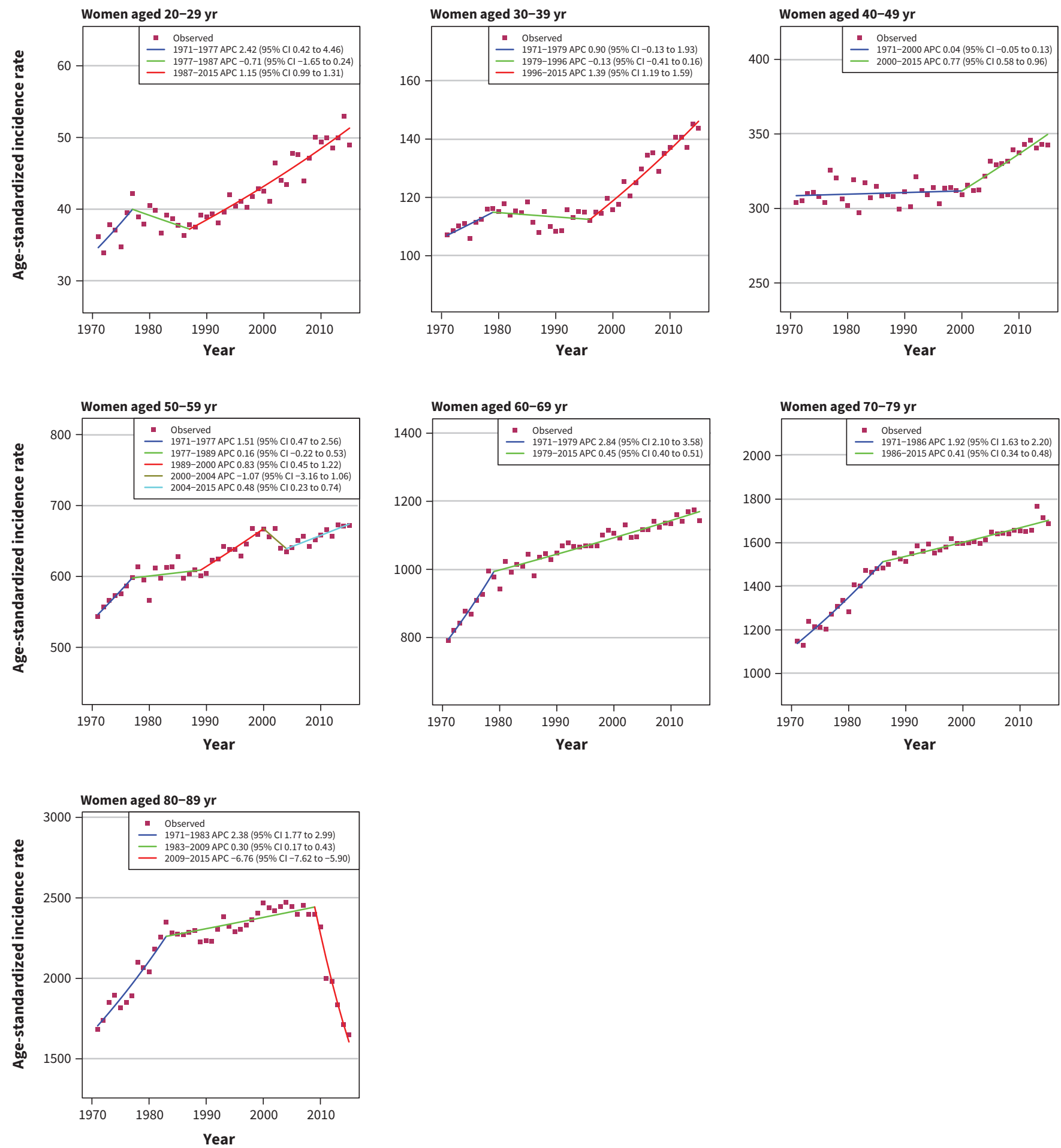

Figure 2: Age-standardized incidence rates of all cancers in women in Canada (1971-2015). Note: APC = annual percent change, $\mathrm{Cl}=$ confidence interval. 
Table 2: Age-standardized annual percent changes of the most recent trend ${ }^{\star}$ for selected cancer sites

\begin{tabular}{|c|c|c|c|c|c|c|c|c|}
\hline \multirow{3}{*}{$\begin{array}{l}\text { Cancer site } \\
\text { or type }\end{array}$} & \multirow{3}{*}{$\begin{array}{l}\text { Patient } \\
\text { sex }\end{array}$} & \multicolumn{7}{|c|}{ Patient age, yr } \\
\hline & & $20-29$ & $30-39$ & 40-49 & $50-59$ & $60-69$ & $70-79$ & 80-89 \\
\hline & & \multicolumn{7}{|c|}{ Annual percent change $(95 \% \mathrm{Cl})$} \\
\hline \multirow[t]{2}{*}{ Anus } & $\mathrm{F}$ & \multicolumn{3}{|c|}{$-4.71(-10.06$ to 0.97$) \dagger$} & 4.13 (3.12 to 5.16$)$ & $\begin{array}{c}2.16(1.66 \text { to } \\
2.66)\end{array}$ & $\begin{array}{c}0.64 \text { (0.09 to } \\
1.19)\end{array}$ & $\begin{array}{c}-3.56(-5.67 \text { to } \\
-1.40)\end{array}$ \\
\hline & M & \multicolumn{3}{|c|}{$2.08(1.22$ to 2.94$) \dagger$} & $\begin{array}{c}0.46(-0.32 \text { to } \\
1.25)\end{array}$ & $\begin{array}{c}-0.60(-1.40 \text { to } \\
0.21)\end{array}$ & $\begin{array}{c}-3.48(-5.21 \text { to } \\
-1.72)\end{array}$ & $\begin{array}{c}-4.74(-7.42 \text { to } \\
-1.98)\end{array}$ \\
\hline \multirow[t]{2}{*}{ Bladder } & $\mathrm{F}$ & \multicolumn{2}{|c|}{$-1.66(-2.37$ to -0.95$) \dagger$} & $\begin{array}{c}-2.64(-3.37 \text { to } \\
-1.91)\end{array}$ & $\begin{array}{c}-1.05(-1.40 \text { to } \\
-0.69)\end{array}$ & $\begin{array}{c}-0.30(-0.54 \text { to } \\
-0.05)\end{array}$ & $\begin{array}{c}-0.07(-0.30 \text { to } \\
0.16)\end{array}$ & $\begin{array}{c}-4.12(-5.33 \text { to } \\
-2.89)\end{array}$ \\
\hline & M & \multicolumn{2}{|c|}{$-2.77(-3.31$ to -2.22$) \dagger$} & $\begin{array}{c}-2.02(-2.37 \text { to } \\
-1.67)\end{array}$ & $\begin{array}{c}-1.49(-1.77 \text { to } \\
-1.21)\end{array}$ & $\begin{array}{c}-0.92(-1.15 \text { to } \\
-0.70)\end{array}$ & $\begin{array}{c}-0.38(-0.57 \text { to } \\
-0.18)\end{array}$ & $\begin{array}{c}-5.13(-7.39 \text { to } \\
-2.81)\end{array}$ \\
\hline Breast & $\mathrm{F}$ & $\begin{array}{c}2.92 \text { (1.87 to } \\
3.99)\end{array}$ & $\begin{array}{c}0.01(-0.08 \text { to } \\
0.11)\end{array}$ & $\begin{array}{c}0.05(-0.02 \text { to } \\
0.12)\end{array}$ & $\begin{array}{c}-0.40(-0.84 \text { to } \\
0.05)\end{array}$ & $\begin{array}{c}0.03(-0.25 \text { to } \\
0.30)\end{array}$ & $\begin{array}{c}0.85 \text { (0.29 to } \\
1.41)\end{array}$ & $\begin{array}{c}-6.60(-7.92 \text { to } \\
-5.25)\end{array}$ \\
\hline Cervix & $\mathrm{F}$ & $\begin{array}{c}-2.01(-2.37 \text { to } \\
-1.64)\end{array}$ & $\begin{array}{c}-0.33(-1.16 \text { to } \\
0.50)\end{array}$ & $\begin{array}{c}-0.61(-0.98 \text { to } \\
-0.24)\end{array}$ & $\begin{array}{c}-1.33(-1.66 \text { to } \\
-1.00)\end{array}$ & $\begin{array}{c}-1.52(-2.86 \text { to } \\
-0.16)\end{array}$ & $\begin{array}{c}-3.50(-3.73 \text { to } \\
-3.27)\end{array}$ & $\begin{array}{c}-8.80(-11.78 \text { to } \\
-5.71)\end{array}$ \\
\hline \multirow[t]{2}{*}{ Colorectal } & $\mathrm{F}$ & $\begin{array}{c}7.22 \text { (4.56 to } \\
9.95)\end{array}$ & $\begin{array}{l}2.98 \text { (2.06 to } \\
3.92)\end{array}$ & $\begin{array}{l}1.97(1.00 \text { to } \\
2.95)\end{array}$ & $\begin{array}{c}-0.13(-0.42 \text { to } \\
0.16)\end{array}$ & $\begin{array}{c}-0.76(-0.86 \text { to } \\
-0.65)\end{array}$ & $\begin{array}{c}-2.29(-3.09 \text { to } \\
-1.49)\end{array}$ & $\begin{array}{c}-9.03(-10.56 \text { to } \\
-7.47)\end{array}$ \\
\hline & M & $\begin{array}{c}6.36(4.71 \text { to } \\
8.05)\end{array}$ & $\begin{array}{c}5.29(4.27 \text { to } \\
6.31)\end{array}$ & $\begin{array}{c}1.94(1.30 \text { to } \\
2.57)\end{array}$ & $\begin{array}{c}-1.03(-1.67 \text { to } \\
-0.38)\end{array}$ & $\begin{array}{c}-2.54(-3.17 \text { to } \\
-1.91)\end{array}$ & $\begin{array}{c}-1.92(-2.49 \text { to } \\
-1.34)\end{array}$ & $\begin{array}{c}-5.29(-6.32 \text { to } \\
-4.24)\end{array}$ \\
\hline Uterine & $\mathrm{F}$ & $\begin{array}{c}1.06(-0.81 \text { to } \\
2.97)\end{array}$ & $\begin{array}{l}3.65(2.70 \text { to } \\
4.61)\end{array}$ & $\begin{array}{c}2.67(1.94 \text { to } \\
3.40)\end{array}$ & 1.22 (1.03 to 1.41$)$ & $\begin{array}{c}2.68(2.21 \text { to } \\
3.16)\end{array}$ & $\begin{array}{c}2.97 \text { (2.24 to } \\
3.71)\end{array}$ & $\begin{array}{c}-2.26(-2.82 \text { to } \\
-1.70)\end{array}$ \\
\hline \multirow[t]{2}{*}{ Kidney } & $\mathrm{F}$ & $\begin{array}{c}2.91 \text { (2.14 to } \\
3.68)\end{array}$ & $\begin{array}{l}2.13(1.64 \text { to } \\
2.61)\end{array}$ & $\begin{array}{c}0.84 \text { (0.34 to } \\
1.35)\end{array}$ & 0.99 (0.64 to 1.35 ) & $\begin{array}{c}0.97 \text { (0.69 to } \\
1.25)\end{array}$ & $\begin{array}{c}-1.92(-4.23 \text { to } \\
0.46)\end{array}$ & $\begin{array}{c}-7.43(-10.96 \text { to } \\
-3.76)\end{array}$ \\
\hline & M & $\begin{array}{c}0.98(0.23 \text { to } \\
1.74)\end{array}$ & $\begin{array}{l}2.04 \text { (1.56 to } \\
2.53)\end{array}$ & $\begin{array}{c}2.99 \text { (2.33 to } \\
3.65)\end{array}$ & 1.11 (0.92 to 1.29$)$ & $\begin{array}{l}1.61(1.17 \text { to } \\
2.05)\end{array}$ & $\begin{array}{c}1.25(0.90 \text { to } \\
1.61)\end{array}$ & $\begin{array}{c}-6.77(-9.23 \text { to } \\
-4.25)\end{array}$ \\
\hline \multirow[t]{2}{*}{ Liver } & $\mathrm{F}$ & \multicolumn{2}{|c|}{$-0.78(-1.64$ to 0.09$) \dagger$} & $\begin{array}{c}1.14(0.25 \text { to } \\
2.03)\end{array}$ & 3.28 (1.46 to 5.14$)$ & $\begin{array}{l}1.54 \text { (1.10 to } \\
1.99)\end{array}$ & $\begin{array}{l}2.12(1.48 \text { to } \\
2.77)\end{array}$ & $\begin{array}{c}-0.34(-0.78 \text { to } \\
0.09)\end{array}$ \\
\hline & M & \multicolumn{2}{|c|}{$0.95(0.14$ to 1.77$) \dagger$} & $\begin{array}{c}-1.34(-3.36 \text { to } \\
0.72)\end{array}$ & $\begin{array}{c}-1.62(-3.68 \text { to } \\
0.49)\end{array}$ & $\begin{array}{c}6.73 \text { (3.03 to } \\
10.56)\end{array}$ & $\begin{array}{c}2.44(2.21 \text { to } \\
2.66)\end{array}$ & 1.55 (1.15 to 1.95$)$ \\
\hline \multirow[t]{2}{*}{ Lung } & $\mathrm{F}$ & $\begin{array}{c}0.38(-0.47 \text { to } \\
1.23)\end{array}$ & $\begin{array}{c}-5.31(-6.42 \text { to } \\
-4.20)\end{array}$ & $\begin{array}{c}-6.27(-7.34 \text { to } \\
-5.18)\end{array}$ & $\begin{array}{c}-0.52(-0.72 \text { to } \\
-0.31)\end{array}$ & $\begin{array}{c}-1.04(-1.57 \text { to } \\
-0.51)\end{array}$ & $\begin{array}{c}1.07 \text { (0.61 to } \\
1.53 \text { ) }\end{array}$ & $\begin{array}{c}-3.78(-4.92 \text { to } \\
-2.63)\end{array}$ \\
\hline & M & $\begin{array}{c}-0.36(-1.24 \text { to } \\
0.53)\end{array}$ & $\begin{array}{c}-5.82(-7.07 \text { to } \\
-4.56)\end{array}$ & $\begin{array}{c}-7.42(-9.02 \text { to } \\
-5.79)\end{array}$ & $\begin{array}{c}-3.14(-3.47 \text { to } \\
-2.82)\end{array}$ & $\begin{array}{c}-2.83(-2.95 \text { to } \\
-2.70)\end{array}$ & $\begin{array}{c}-1.52(-1.66 \text { to } \\
-1.37)\end{array}$ & $\begin{array}{c}-4.33(-5.13 \text { to } \\
-3.53)\end{array}$ \\
\hline \multirow[t]{2}{*}{ Melanoma } & $\mathrm{F}$ & $\begin{array}{c}0.26(-0.10 \text { to } \\
0.63)\end{array}$ & $\begin{array}{c}0.13(-0.14 \text { to } \\
0.40)\end{array}$ & $\begin{array}{c}2.24 \text { (1.33 to } \\
3.16)\end{array}$ & 1.94 (1.74 to 2.13 ) & $\begin{array}{c}4.97 \text { (3.97 to } \\
5.99)\end{array}$ & $\begin{array}{c}2.94(2.75 \text { to } \\
3.13)\end{array}$ & $\begin{array}{c}-1.13(-3.07 \text { to } \\
0.85)\end{array}$ \\
\hline & M & $\begin{array}{c}-2.59(-4.34 \text { to } \\
-0.80)\end{array}$ & $\begin{array}{c}1.09(0.25 \text { to } \\
1.93)\end{array}$ & $\begin{array}{c}0.03(-0.22 \text { to } \\
0.28)\end{array}$ & 1.08 (0.81 to 1.35 ) & $\begin{array}{c}2.76(2.51 \text { to } \\
3.01)\end{array}$ & $\begin{array}{c}3.87 \text { (3.58 to } \\
4.16)\end{array}$ & 4.03 (3.69 to 4.37$)$ \\
\hline \multirow{2}{*}{$\begin{array}{l}\text { Non- } \\
\text { Hodgkin } \\
\text { lymphoma }\end{array}$} & $\mathrm{F}$ & $\begin{array}{c}7.35 \text { (1.90 to } \\
13.10)\end{array}$ & $\begin{array}{l}5.72(0.60 \text { to } \\
11.09)\end{array}$ & $\begin{array}{c}1.46(-1.02 \text { to } \\
4.00)\end{array}$ & $\begin{array}{c}-0.26(-0.62 \text { to } \\
0.10)\end{array}$ & $\begin{array}{c}0.12(-0.41 \text { to } \\
0.65)\end{array}$ & $\begin{array}{c}1.12 \text { (0.94 to } \\
1.29)\end{array}$ & $\begin{array}{c}-3.23(-4.79 \text { to } \\
-1.64)\end{array}$ \\
\hline & M & $\begin{array}{c}17.44(-2.54 \text { to } \\
41.52)\end{array}$ & $\begin{array}{c}1.29(-0.32 \text { to } \\
2.93)\end{array}$ & $\begin{array}{c}-0.60(-0.93 \text { to } \\
-0.26)\end{array}$ & $\begin{array}{c}-0.18(-0.57 \text { to } \\
0.22)\end{array}$ & $\begin{array}{c}0.98 \text { (0.81 to } \\
1.14)\end{array}$ & $\begin{array}{c}1.32 \text { (1.13 to } \\
1.51)\end{array}$ & $0.51(-0.07$ to 1.10$)$ \\
\hline Ovary & $\mathrm{F}$ & $\begin{array}{l}2.31(0.54 \text { to } \\
4.11)\end{array}$ & $\begin{array}{c}-1.21(-1.47 \text { to } \\
-0.95)\end{array}$ & $\begin{array}{c}0.70(-0.06 \text { to } \\
1.46)\end{array}$ & $\begin{array}{c}-1.15(-1.32 \text { to } \\
-0.99)\end{array}$ & $\begin{array}{c}-1.04(-1.19 \text { to } \\
-0.89)\end{array}$ & $\begin{array}{c}-0.68(-0.96 \text { to } \\
-0.40)\end{array}$ & $\begin{array}{c}-7.53(-9.43 \text { to } \\
-5.59)\end{array}$ \\
\hline \multirow[t]{2}{*}{ Pancreas } & $\mathrm{F}$ & \multicolumn{2}{|c|}{$1.11(0.27$ to 1.95$) \dagger$} & $\begin{array}{c}-8.82(-17.59 \text { to } \\
0.89)\end{array}$ & $\begin{array}{c}-0.08(-0.26 \text { to } \\
0.10)\end{array}$ & $\begin{array}{c}-0.07(-0.25 \text { to } \\
0.12)\end{array}$ & $\begin{array}{c}-0.22(-0.42 \text { to } \\
-0.02)\end{array}$ & $\begin{array}{c}-7.19(-8.77 \text { to } \\
-5.57)\end{array}$ \\
\hline & M & \multicolumn{2}{|c|}{$5.74(0.99$ to 10.72$) \dagger$} & $\begin{array}{c}1.91(0.22 \text { to } \\
3.63)\end{array}$ & $\begin{array}{c}-0.77(-0.98 \text { to } \\
-0.56)\end{array}$ & $\begin{array}{c}-6.93(-19.15 \text { to } \\
7.12)\end{array}$ & $\begin{array}{c}0.09(-0.33 \text { to } \\
0.50)\end{array}$ & $\begin{array}{c}-13.66(-25.78 \text { to } \\
0.44)\end{array}$ \\
\hline Prostate & M & \multicolumn{2}{|c|}{$-1.11(-2.01$ to -0.19$) \dagger$} & $\begin{array}{c}-11.11(-15.93 \\
\text { to }-6.01)\end{array}$ & $\begin{array}{c}-6.32(-7.61 \text { to } \\
-5.01)\end{array}$ & $\begin{array}{c}-6.41(-7.42 \text { to } \\
-5.38)\end{array}$ & $\begin{array}{c}-5.35(-6.32 \text { to } \\
-4.37)\end{array}$ & $\begin{array}{c}-9.18(-10.79 \text { to } \\
-7.53)\end{array}$ \\
\hline \multirow[t]{2}{*}{ Stomach } & $\mathrm{F}$ & \multicolumn{2}{|c|}{$-0.80(-1.35$ to -0.25$) \dagger$} & $\begin{array}{c}0.23(-0.78 \text { to } \\
1.25)\end{array}$ & $\begin{array}{c}0.83(-1.11 \text { to } \\
2.82)\end{array}$ & $\begin{array}{c}9.74(-5.14 \text { to } \\
26.94)\end{array}$ & $\begin{array}{c}-2.46(-2.62 \text { to } \\
-2.30)\end{array}$ & $\begin{array}{c}-9.23(-12.00 \text { to } \\
-6.37)\end{array}$ \\
\hline & M & \multicolumn{2}{|c|}{$-0.42(-1.16$ to 0.33$) \dagger$} & $\begin{array}{c}0.84(-1.13 \text { to } \\
2.85)\end{array}$ & 3.05 (0.90 to 5.25$)$ & $\begin{array}{c}-2.37(-2.52 \text { to } \\
-2.22)\end{array}$ & $\begin{array}{c}-1.82(-2.33 \text { to } \\
-1.30)\end{array}$ & $\begin{array}{c}-0.56(-5.13 \text { to } \\
4.22)\end{array}$ \\
\hline \multirow[t]{2}{*}{ Thyroid } & $\mathrm{F}$ & $\begin{array}{c}1.87(0.27 \text { to } \\
3.49)\end{array}$ & $\begin{array}{c}-4.39(-15.16 \text { to } \\
7.75)\end{array}$ & $\begin{array}{l}5.58(4.45 \text { to } \\
6.73)\end{array}$ & $\begin{array}{c}-3.15(-10.82 \text { to } \\
5.18)\end{array}$ & $\begin{array}{c}2.07(-1.79 \text { to } \\
6.08)\end{array}$ & $\begin{array}{l}7.06(6.38 \text { to } \\
7.75)\end{array}$ & 3.36 (2.12 to 4.61$)$ \\
\hline & M & $\begin{array}{c}3.24 \text { (2.69 to } \\
3.78)\end{array}$ & $\begin{array}{c}7.04 \text { (6.04 to } \\
8.05)\end{array}$ & $\begin{array}{c}8.00 \text { (7.23 to } \\
8.77)\end{array}$ & 6.04 (5.41 to 6.66 ) & $\begin{array}{c}6.60(5.77 \text { to } \\
7.44)\end{array}$ & $\begin{array}{c}5.62(4.93 \text { to } \\
6.31)\end{array}$ & 1.11 (0.49 to 1.72$)$ \\
\hline
\end{tabular}


30-69 years, except for a large decrease in the group aged 50-59 years during $1999-2005$ (APC $-2.38,95 \% \mathrm{Cl}-3.73$ to -1.01 ). In the group aged $70-79$ years, the rates steadily declined from 1992 to 2005 (APC $-0.95,95 \% \mathrm{Cl}-1.40$ to -0.49 ), followed by an increasing trend from 2005 to 2015 (APC $0.85,95 \% \mathrm{Cl} 0.29$ to 1.41 ). There has been a large decrease in the incidence rates among women aged
80-89 years (APC $-6.60,95 \% \mathrm{Cl}-7.92$ to -5.25 ). Of note, there has been a considerable increase in the incidence of breast cancer among women aged 20-29 years since 1998 (APC 2.92, 95\% Cl 1.87 to 3.99).

Increases in lung cancer rates among women were observed for all age groups (except 20-29 yr) beginning in 1971. More recently, trends have decreased (except 70-79 yr), with rates in women aged
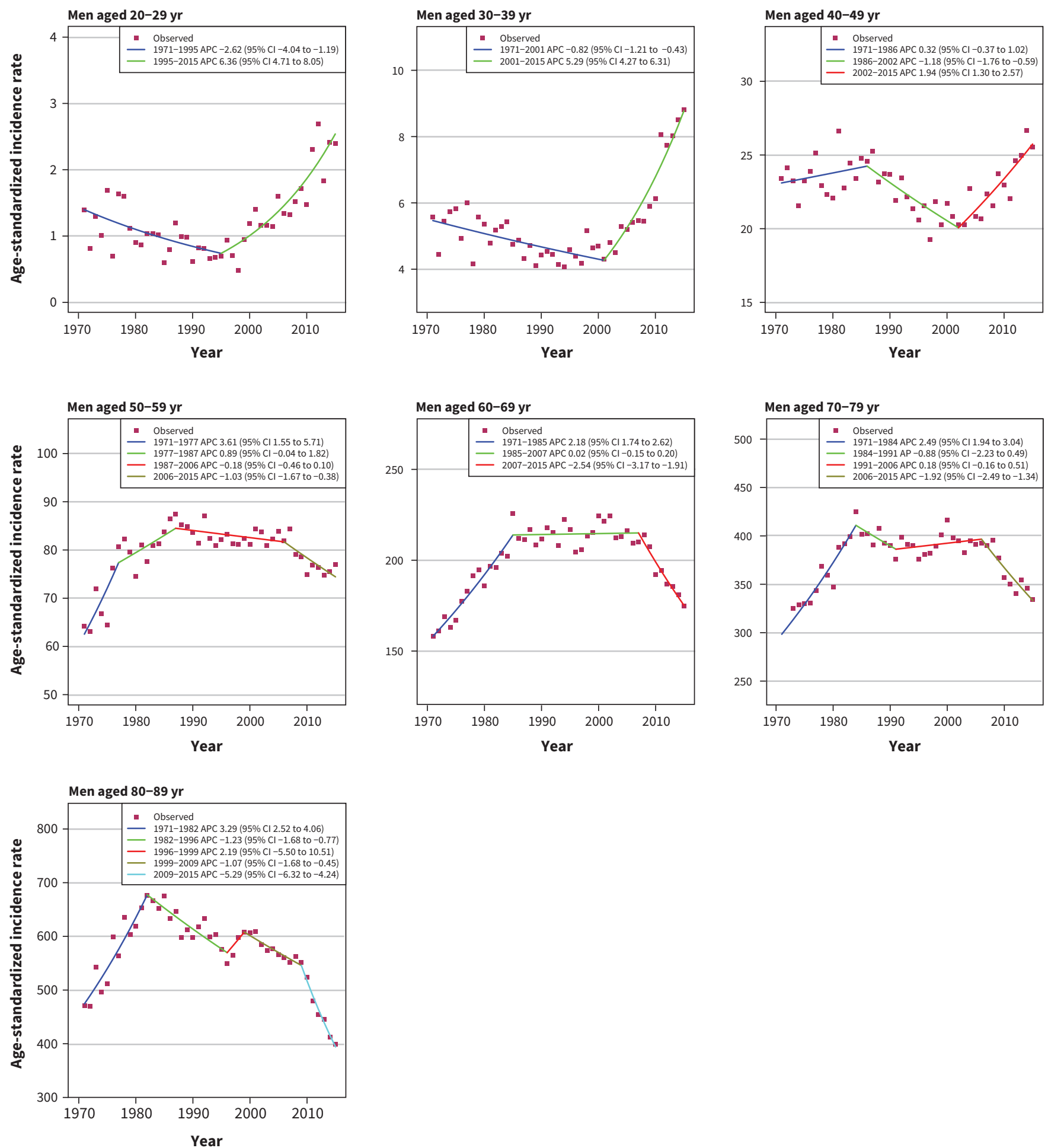

Figure 3: Age-standardized incidence rates of colorectal cancer in men in Canada (1971-2015). Note: APC = annual percent change, $\mathrm{Cl}=$ confidence interval. 
30-49 years now similar to those observed in 1971 (30-39 yr: 1.57 per 100000 in 1971, 2.03 per 100000 in 2015; 40-49 yr: 11.33 per 100000 in 1971 and 11.79 per 100000 in 2015) (Appendix 3). Recent large decreasing trends have been observed among women aged 30-39 years (APC $-5.31,95 \% \mathrm{Cl}-6.42$ to -4.20 ), $40-49$ years (APC $-6.27,95 \%$ $\mathrm{Cl}-7.34$ to -5.18 ) and $89-89$ years (APC $-3.78,95 \% \mathrm{Cl}-4.92$ to -2.63 ).
Trends for colorectal cancer among women were similar to those observed among men (Figure 5). Incidence has increased in younger age groups (20-29 yr: APC 7.22, 95\% Cl 4.56 to 9.95; 30-39 yr: APC 2.98, 95\% Cl 2.06 to 3.92; 40-49 yr: APC 1.97, 95\% Cl 1.00 to 2.95$)$ and remained steady or decreased in older age groups (50-59 yr: APC $-0.13,95 \% \mathrm{Cl}-0.42$ to 0.16 ; 60-69 yr: APC
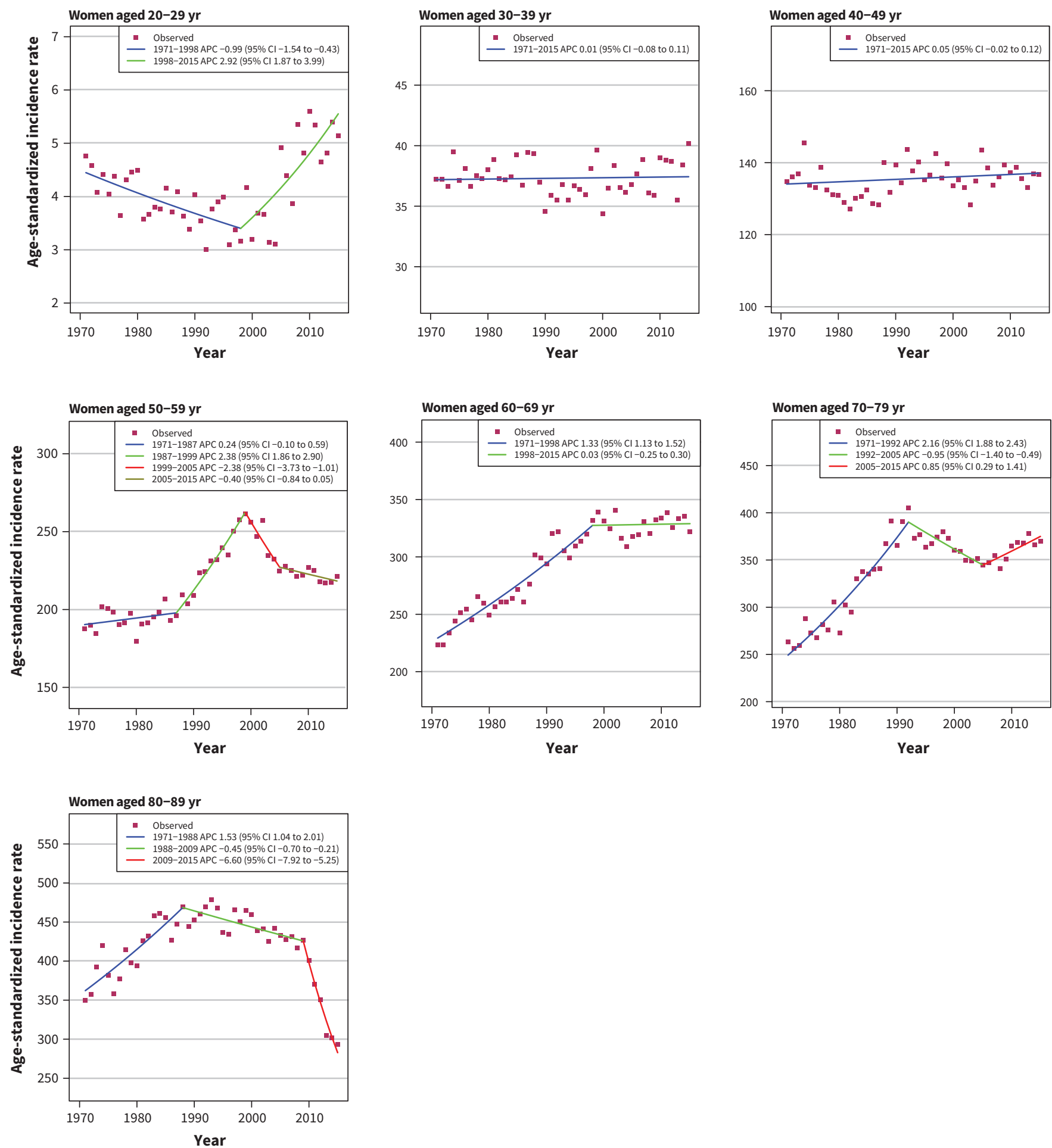

Figure 4: Age-standardized incidence rates of breast cancer in women in Canada (1971-2015). Note: APC = annual percent change, $\mathrm{Cl}=$ confidence interval. 
$-0.76,95 \% \mathrm{Cl}-0.86$ to $-0.65 ; 70-79 \mathrm{yr}:$ APC $-2.29,95 \% \mathrm{Cl}-3.09$ to -1.49 ; 80-89 yr: APC $-9.03,95 \% \mathrm{Cl}-10.56$ to -7.47$)$.

\section{Cohort effects}

Using 1941-1945 as the reference category, we observed that more recent cohorts had numerically increasing IRRs for all can- cers combined (among women and men), but trends have not reached significance (Appendix 4, available at www.cmaj.ca/ lookup/suppl/doi:10.1503/cmaj.190355/-/DC1). Among women, significant increased rate ratios were observed for melanoma, and kidney and thyroid cancer, and significant decreases were observed for cervical and ovarian cancer. Numerically but not
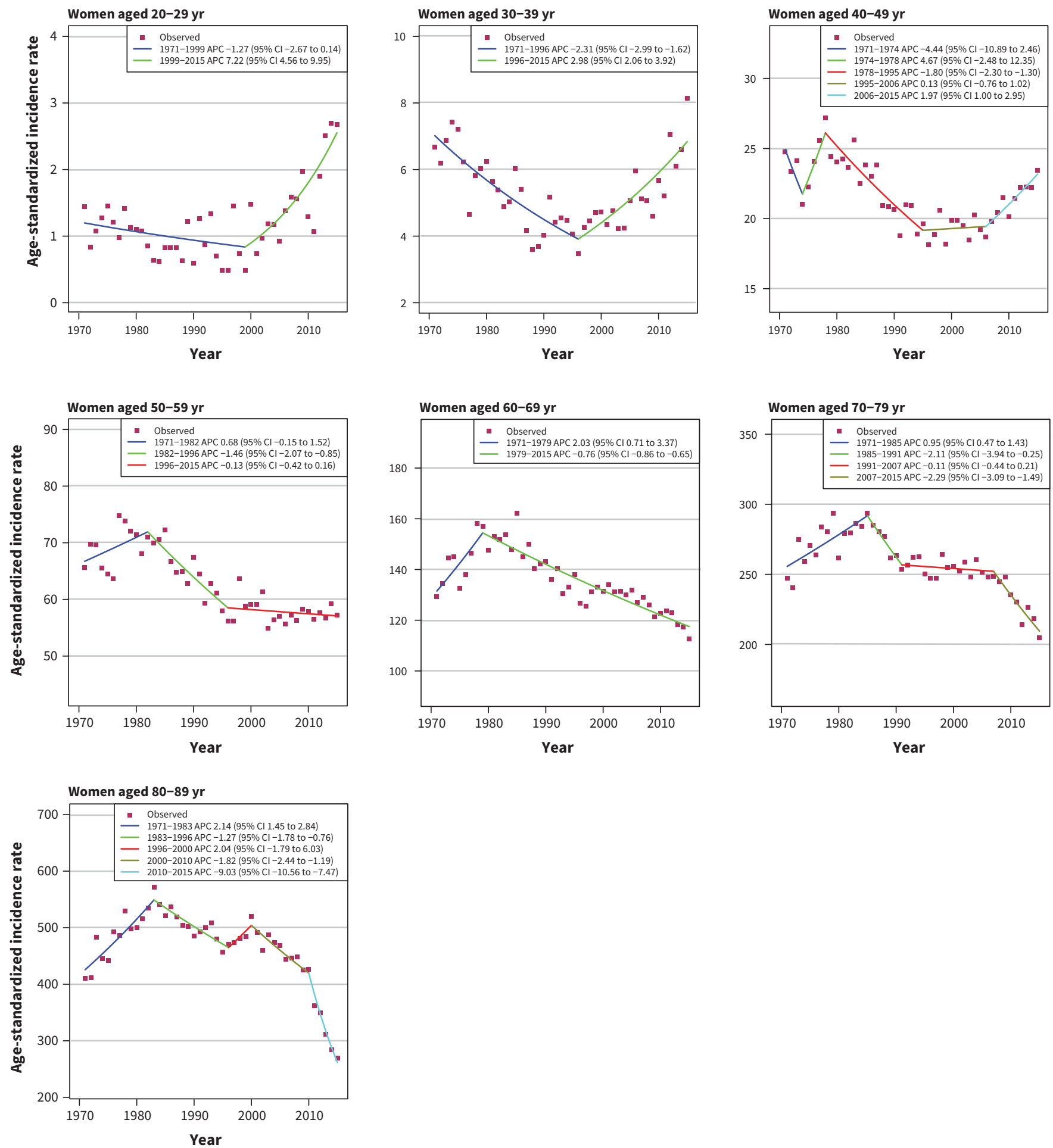

Figure 5: Age-standardized incidence rates of colorectal cancer in women in Canada (1971-2015). Note: APC = annual percent change, $\mathrm{Cl}=$ confidence interval. 
significantly increasing trends were also seen for breast, pancreatic, esophageal and colorectal cancer $(p>0.05)$, and decreasing trends for stomach cancers $(p>0.05)$.

For men, younger cohorts had increased rate ratios compared with the reference cohort for melanoma, prostate, thyroid, anal, kidney, esophageal and liver cancer. Despite these increases, the most recent 1986-1990 cohort appeared to reverse the trend for anal, kidney and liver cancers. The 1986-1990 cohort had a lower incidence compared with the reference cohort for melanoma and esophageal cancer.

\section{Sensitivity analysis}

To determine robustness to imputation methods for the final 4 years of Quebec incidence data, we repeated our analyses excluding this province. These age-standardized incidence trends are presented in Appendix 5 (available at www.cmaj.ca/ lookup/suppl/doi:10.1503/cmaj.190355/-/DC1) and agestandardized APCs excluding Quebec are presented in Appendix 6 (available at www.cmaj.ca/lookup/suppl/doi:10.1503/ cmaj.190355/-/DC1). Overall, the results are consistent with the Canada-wide analyses, with the exception of anal cancer among older age groups and thyroid cancer in younger age groups.

\section{Interpretation}

Consistent with previous research, ${ }^{1}$ this extensive analysis of trends in cancer rates in Canada shows that the overall incidence is decreasing among men but increasing among women. The age- and site-standardized trends we observed have several implications for cancer control in Canada. Additionally, results from the birth-cohort analysis provide evidence that may be useful to guide future research.

As the birth-cohort analysis and age-group analysis were based on the same data, they should show trends that are consistent, but the 2 analyses have different purposes. The age-group analysis shows age-specific incidence rates over a period of time. This is useful in identifying changes in practice such as implementation of screening programs, improved diagnosis and changes in coding, as well as a potential shift in risk factors. In contrast, the cohort analysis shows age-standardized IRRs over birth cohorts, which is specific for detecting changes in risk factors. For example, we observed a rise in the lung-cancer incidence rate in the earlier male birth cohorts, with a continuous decrease in the later cohorts, which aligns with the smoking epidemics in the past.

The most striking results from these analyses relate to increasing incidence trends among younger adults for breast, colorectal, pancreatic, endometrial and kidney cancers. Obesity is a risk factor for these cancer sites, ${ }^{12}$ and the rising incidence runs parallel to the growing prevalence of obesity in recent decades. ${ }^{13}$ As previously reported, prevalence of class II and III obesity (body mass index $\geq 35$ ) has increased significantly in all age groups, ${ }^{14}$ but the trend among younger adults is of greater concern because they are ineligible for most cancer screening programs. Relative increases among younger age groups were found for breast cancer, which is a finding consistent with populations in the United States and Europe. ${ }^{15-17}$ This trend among premenopausal women may reflect a change in risk factors, including later age at first childbirth, increased oral contraceptive use and earlier age at menarche. ${ }^{18-29} \mathrm{~A}$ similar trend was noted for colorectal and pancreatic cancer, which has also been seen in the US. ${ }^{30,31}$ These findings solidify the need for public health measures and interventions that address weight management and are aimed at younger adults. In addition, we observed increases in pancreatic cancer and non-Hodgkin lymphoma among women, a new finding.

Incidence reductions for some cancer sites may be related to successes in both primary and secondary cancer prevention. As reported by others, efforts to reduce smoking initiation and promote cessation have resulted in declines in lung-cancer incidence for men older than 40 years starting in the 1980s. ${ }^{32-34}$ This analysis shows that lung cancer rates among women are now also declining in all age groups except the 70-79 years category, in which rates continue to climb. Lower smoking rates may have also contributed to a decrease in incidence of bladder cancer in most age groups, particularly those in the younger age categories. ${ }^{34}$ Rates of breast cancer among older age groups have declined, which could be related to decreased use of hormone therapy among postmenopausal women. ${ }^{35}$ The reduction in melanoma among younger men is probably due to increases in sunsafety behaviours in this demographic group. Further work in primary prevention should be aimed at reducing ultraviolet exposure and alcohol consumption, and promoting healthful diets and exercise to address increased rates of liver and kidney cancer, and melanoma.

Secondary prevention efforts have resulted in significant declines of colorectal and cervical cancer. The recent decreases in rates of colorectal cancer among older adults are likely attributable to the use of first endoscopic and late fecal-based screening programs in Canada, which are recommended for adults aged $50-74$ years. ${ }^{36}$ Similarly, the decline in cervical cancer is largely the result of screening to detect treatable lesions ${ }^{37,38}$ and may be minimally related to vaccination against the human papillomavirus (HPV). ${ }^{39-42}$ Further decreases in incidence of cervical cancer from organized HPV vaccination can be expected, but this effect is probably not apparent in our results. Vaccination programs for HPV began in Canada in $2006,{ }^{43}$ so incidence may continue to decrease as vaccinated cohorts reach ages when cervical cancer is typically diagnosed..$^{44,45}$ However, the use of prostatespecific antigen testing resulted in sharp increases in the incidence of prostate cancer in 1990 and $2007,{ }^{46-49}$ and the overdiagnosis of thyroid cancer has been thoroughly documented. ${ }^{50} \mathrm{New}$ guidelines for prostate cancer screening may be related to decreases in diagnoses in older age groups, ${ }^{48}$ but the trend of increasing rates of thyroid cancer reflects the need for further research to identify tumour types that are more likely to lead to long-term harms. ${ }^{51}$

\section{Limitations}

This analysis was limited by the available incidence data. Our primary analysis relied on cancer incidence that was imputed for the last 4 years of one of the included provinces (Quebec). In addition, we were able to examine incidence trends only up to 
2012 for bladder cancer owing to a recent change in reporting practices in Ontario. Finally, there are subtle differences between provinces in terms of diagnosis and reporting, which could have an influence on our findings. We did not examine any trends in screening, prevalence of risk factors, or other secular trends to examine changes in incidence rates. This could be a point of interest for future research.

Cancer incidence data before 1992 were obtained from the $\mathrm{NCIRS}$, and incidence data after 1992 were obtained from the CCR. The main difference between the 2 databases is that the NCRIS was event-based and the CCR is patient-based. ${ }^{52}$ Data reported to the NCIRS were reformatted to produce standard records for compatibility with the CCR. All records were reviewed to ensure validity, and less than $2 \%$ of records had to be queried by consulting the reporting province. ${ }^{9}$ Although differences in these databases could be a possible source of error, we wanted to include earlier data to provide additional information on trends. However, any joinpoints around 1992 should be interpreted with caution given the change in data source that year.

\section{Conclusion}

Overall, we found large reductions in cancer incidence across age groups for several cancer sites that are probably attributable to efforts in primary and secondary prevention. The overall increase in early-onset cancers, particularly breast and colorectal, highlights the importance of efforts to reduce obesity rates as a measure for cancer prevention. Other successful prevention measures in Canada should continue, and further evidence should be gathered to identify possible emerging risk factors that may be causing cancer in younger cohorts. Future studies should examine similar age-specific incidence trends by province, which may allow the identification of relevant etiologic factors and prevention efforts that are contributing to recent changes.

\section{References}

1. Canadian Cancer Society's Advisory Committee on Cancer Statistics. Canadian Cancer Statistics 2017. Toronto: Canadian Cancer Society; 2017.

2. Brenner DR, Ruan Y, Shaw E, et al. Increasing colorectal cancer incidence trends among younger adults in Canada. Prev Med 2017;105:345-9.

3. National Cancer Incidence Reporting System (1969-1992) [database]. Ottawa: Statistics Canada; 1993.

4. Canadian Cancer Registry (1992-2012) [database]. Ottawa: Statistics Canada; 2013.

5. Canadian Cancer Registry (CCR) system guide - 2010 edition. Ottawa: Statistics Canada; modified 2014 Apr. 4.

6. Union for International Cancer Control (UICC). Cancer registries: Why, what and how? Geneva: International Agency for Research on Cancer, World Health Organization. Available: www.uicc.org/sites/main/files/atoms/files/UICC\%20 Cancer\%20Registries-\%20why\%20what\%20how.pdf (accessed 2019 June 12).

7. Jump Model and Comparability Ratio Model. Bethesda (MD): National Cancer Institute, Division of Cancer Control and Population Sciences; 2019. Available: https://surveillance.cancer.gov/joinpoint/jump.html (accessed 2019 July 22).

8. Carpenter M, Fair ME, Polliquin C, et al. Canadian cancer data base, 1969 to 1991 history and development. Occupational and Environmental Health Research Section, Report no 16. Ottawa: Statistics Canada; 2008.

9. Gaudette LA, Lee J. Cancer incidence in Canada, 1969-1993. Cat no 82-566-XPB. Ottawa: Statistics Canada; 1997.

10. Joinpoint. Bethesda (MD): National Cancer Institute, Division of Cancer Control and Population Sciences. Available: https://surveillance.cancer.gov/help/ joinpoint (accessed 2019 Mar. 6).
11. Rosenberg PS, Check DP, Anderson WF. A web tool for age-period-cohort analysis of cancer incidence and mortality rates. Cancer Epidemiol Biomarkers Prev 2014;23:2296-302.

12. Lauby-Secretan B, Scoccianti C, Loomis D, et al.; International Agency for Research on Cancer Handbook Working Group. Body fatness and cancer Viewpoint of the IARC Working Group. N Engl J Med 2016;375:794-8.

13. Body-mass index: evolution of BMI over time. NCD Risk Factor Collaboration; 2017. Available: http://ncdrisc.org/obesity-prevalence-line-ado.html (accessed 2019 Feb. 8).

14. Brenner DR, Ruan Y, Shaw E, et al. Increasing colorectal cancer incidence trends among younger adults in Canada. Prev Med 2017;105:345-9.

15. Johnson RH, Chien FL, Bleyer A. Incidence of breast cancer with distant involvement among women in the United States, 1976 to 2009. JAMA 2013;309:800-5.

16. Merlo DF, Ceppi M, Filiberti R, et al.; AIRTUM WG. Breast cancer incidence trends in European women aged 20-39 years at diagnosis. Breast Cancer Res Treat 2012;134:363-70.

17. Leclère B, Molinié $F$, Trétarre B, et al.; GRELL Working Group. Trends in incidence of breast cancer among women under 40 in seven European countries: a GRELL cooperative study. Cancer Epidemiol 2013;37:544-9.

18. Hajiebrahimi M, Cnattingius S, Lambe M, et al. Pregnancy history and risk of premenopausal breast cancer-a nested case-control study. Int J Epidemiol 2016;45:816-24.

19. Chollet-Hinton L, Anders CK, Tse CK, et al. Breast cancer biologic and etiologic heterogeneity by young age and menopausal status in the Carolina Breast Cancer Study: a case-control study. Breast Cancer Res 2016;18:79.

20. Kahlenborn C, Modugno F, Potter DM, et al. Oral contraceptive use as a risk factor for premenopausal breast cancer: a meta-analysis. Mayo Clin Proc 2006; 81:1290-302.

21. Chie WC, Li CY, Huang CS, et al. Oral contraceptives and breast cancer risk in Taiwan, a country of low incidence of breast cancer and low use of oral contraceptives. Int J Cancer 1998;77:219-23.

22. Chollet-Hinton L, Olshan AF, Nichols HB, et al. Biology and etiology of youngonset breast cancers among premenopausal African American women: results from the AMBER Consortium. Cancer Epidemiol Biomarkers Prev 2017;26:1722-9.

23. Wynder EL, MacCornack FA, Stellman SD. The epidemiology of breast cancer in 785 United States Caucasian women. Cancer 1978;41:2341-54.

24. Ronco AL, De Stefani E, Deneo-Pellegrini H. Risk factors for premenopausal breast cancer: a case-control study in Uruguay. Asian Pac J Cancer Prev 2012;13:2879-86.

25. Unar-Munguía M, Torres-Mejía G, Colchero MA, et al. Breastfeeding mode and risk of breast cancer: a dose-response meta-analysis. J Hum Lact 2017;33:422-34.

26. O’Brien KM, Sun J, Sandler DP, et al. Risk factors for young-onset invasive and in situ breast cancer. Cancer Causes Control 2015;26:1771-8.

27. Stavraky K, Emmons S. Breast cancer in premenopausal and postmenopausal women. J Natl Cancer Inst 1974;53:647-54.

28. Cotterchio M, Kreiger N, Theis B, et al. Hormonal factors and the risk of breast cancer according to estrogen- and progesterone-receptor subgroup. Cancer Epidemiol Biomarkers Prev 2003;12:1053-60.

29. Gajalakshmi CK, Shanta V. Risk factors for female breast cancer. A hospitalbased case-control study in Madras, India. Acta Oncol 1991;30:569-74.

30. Austin $\mathrm{H}$, Henley SJ, King J, et al. Changes in colorectal cancer incidence rates in young and older adults in the United States: What does it tell us about screening? Cancer Causes Control 2014;25:191-201.

31. Gordon-Dseagu VL, Devesa SS, Goggins M, et al. Pancreatic cancer incidence trends: evidence from the Surveillance, Epidemiology and End Results (SEER) population-based data. Int J Epidemiol 2018;47:427-39.

32. Pechmann C, Reibling ET. Anti-smoking advertising campaigns targeting youth: case studies from USA and Canada. Tob Control 2000;9(Suppl 2):II18-31.

33. Flay BR. Mass media and smoking cessation: a critical review. Am J Public Health 1987;77:153-60.

34. Reid JL, Hammond D, Rynard VL, et al. Tobacco use in Canada: patterns and trends, 2017 edition. Waterloo: Propel Centre for Population Health Impact, University of Waterloo; 2017

35. De P, Neutel $\mathrm{Cl}$, Olivotto I, et al. Breast cancer incidence and hormone replacement therapy in Canada. J Natl Cancer Inst 2010;102:1489-95.

36. Leddin D, Hunt R, Champion M, et al.; Canadian Association of Gastroenterology. Canadian Digestive Health Foundation. Canadian Association of Gastroenterology and the Canadian Digestive Health Foundation: guidelines on colon cancer screening. Can J Gastroenterol 2004;18:93-9. 
37. Dickinson J, Tsakonas E, Conner Gorber S, et al.; Canadian Task Force on Preventive Health Care. Recommendations on screening for cervical cancer. CMAJ 2013;185:35-45.

38. Dickinson JA, Stankiewicz A, Popadiuk C, et al. Reduced cervical cancer incidence and mortality in Canada: national data from 1932 to 2006. BMC Public Health 2012;12:992.

39. Ogilvie GS, Naus M, Money DM, et al. Reduction in cervical intraepithelial neoplasia in young women in British Columbia after introduction of the HPV vaccine: an ecological analysis. Int J Cancer 2015;137:1931-7.

40. Mahmud SM, Kliewer EV, Lambert $P$, et al. Effectiveness of the quadrivalent human papillomavirus vaccine against cervical dysplasia in Manitoba, Canada. J Clin Oncol 2014;32:438-43.

41. Smith LM, Strumpf EC, Kaufman JS, et al. The early benefits of human papillomavirus vaccination on cervical dysplasia and anogenital warts. Pediatrics 2015;135:e1131-40

42. Garland SM, Kjaer SK, Muñoz N, et al. Impact and effectiveness of the quadrivalent human papillomavirus vaccine: a systematic review of 10 years of realworld experience. Clin Infect Dis 2016;63:519-27.

43. Bird $\mathrm{Y}$, Obidiya $\mathrm{O}$, Mahmood R, et al. Human papillomavirus vaccination uptake in Canada: a systematic review and meta-analysis. Int J Prev Med 2017; $8: 71$
44. Drolet M, Bénard É, Boily MC, et al. Population-level impact and herd effects following human papillomavirus vaccination programmes: a systematic review and meta-analysis. Lancet Infect Dis 2015;15:565-80.

45. Van Kriekinge G, Castellsagué X, Cibula D, et al. Estimation of the potential overall impact of human papillomavirus vaccination on cervical cancer cases and deaths. Vaccine 2014;32:733-9.

46. Levy I. Prostate cancer: the epidemiologic perspective. Can J Oncol 1994;4 (Suppl 1):4-7.

47. Fradet $\mathrm{Y}, \mathrm{Klotz} \mathrm{L}$, Trachtenberg J, et al. The burden of prostate cancer in Can ada. Can Urol Assoc J 2009;3(Suppl 2):S92-100.

48. Bell N, Connor Gorber S, Shane A, et al.; Canadian Task Force on Preventive Health Care. Recommendations on screening for prostate cancer with the prostate-specific antigen test. CMAJ 2014;186:1225-34.

49. Jeffcott M, Cagiannos I, Zorn KC. Movember update: the Canadian perspective. Can Urol Assoc J 2012;6:E111-4.

50. Vaccarella S, Franceschi S, Bray F, et al. Worldwide thyroid-cancer epidemic? The increasing impact of overdiagnosis. N Engl J Med 2016;375:614-7.

51. Topstad D, Dickinson JA. Thyroid cancer incidence in Canada: a national cancer registry analysis. CMAJ Open 2017;5:E612-6.

52. Band PR, Gaudette LA, Hill GB, et al. The making of the Canadian cancer registry: cancer incidence in Canada and its regions, 1969 to 1988. Ottawa: Statistics Canada; 1993.

\section{Competing interests: None declared.}

This article has been peer reviewed.

Affiliations: Departments of Oncology and Community Health Sciences (Brenner, Friedenreich), Cumming School of Medicine, University of Calgary; Department of Cancer Epidemiology and Prevention Research (Brenner, Ruan, Shaw, Poirier, Heer, Friedenreich), CancerControl Alberta, Alberta Health Services, Calgary, Alta.; Department of Public Health Sciences (O'Sullivan), Queen's University, Kingston, Ont.; Department of Health Sciences (Villeneuve), Carleton University, Ottawa, Ont.; Department of Clinical Epidemiology and Biostatistics (Walter), McMaster University, Hamilton, Ont.; Canadian Cancer Society (Smith); Surveillance and Cancer Registry (De), Cancer Care Ontario, Toronto, Ont.

Contributors: Christine Friedenreich and Darren Brenner were responsible for the study conception. Yibing Ruan, Eileen Shaw, Abbey Poirier, Dylan O'Sullivan, Emily Heer, Paul Villeneuve, Stephen Walter, Darren Brenner, Christine Friedenreich, Leah Smith and Prithwish De contributed substantially to the study design and interpretation of the data.
Yibing Ruan completed the analysis. Abbey Poirier was responsible for acquisition of the data. Eileen Shaw, Emily Heer, Abbey Poirier and Yibing Ruan were responsible for drafting and revising the manuscript. Dylan O'Sullivan, Paul Villeneuve, Stephen Walter, Darren Brenner, Christine Friedenreich, Leah Smith and Prithwish De critically revised the manuscript for important intellectual content. All of the authors gave final approval of version to be published and agreed to be guarantors of the work.

Funding: Darren Brenner was supported by a Career Development Award in Prevention (no. 703917) from the Canadian Cancer Society. Dylan O'Sullivan is supported by a Queen Elizabeth II Scholarship and an Empire Life Fellowship.

Data sharing: Aggregated data can be accessed on a case-by-case basis; contact the corresponding author.

Accepted: Oct. 23, 2019

Correspondence to: Darren Brenner, darren.brenner@ucalgary.ca 